\title{
Kinetic characterization of acetone monooxygenase from Gordonia sp. strain TY-5
}

\author{
Osei Boakye Fordwour ${ }^{1}$, George Luka², Mina Hoorfar ${ }^{2}$ and Kirsten R. Wolthers ${ }^{1 *}$
}

\begin{abstract}
Acetone monooxygenase (ACMO) is a unique member of the Baeyer-Villiger monooxygenase (BVMO) family based on its ability to act on small ketones, such as acetone. Herein, we performed a kinetic analysis of ACMO from the propane-utilizing bacterium Gordonia sp. strain TY-5 to assess its preference for smaller ketone substrates. Steady state kinetic analysis of ACMO with a range of linear (C3-C7) and cyclic ketones (C4-C6) reveals that the enzyme elicits the highest catalytic efficiency towards butanone and cyclobutanone. Stopped-flow and inhibition studies further revealed that $\mathrm{ACMO}$ has a relatively weak binding affinity for the coenzyme with a dissociation constant of $120 \mu \mathrm{M}$. We show through mutagenesis that sequence variation in the residue that coordinates to the 2 '-phosphate of $\mathrm{NADP}(\mathrm{H})$ partially accounts for the weaker binding affinity observed. As for shown for related BVMOs, $\mathrm{NADP}^{+}$stabilizes the C4a-peroxyflavin intermediate in $\mathrm{ACMO}$; however, the rate of its formation is considerably slower in $\mathrm{ACMO}$. The observed rate constant for NADPH-dependent flavin reduction was $60 \mathrm{~s}^{-1}$ at $25^{\circ} \mathrm{C}$, and experiments performed with 4(R)-[4- $\left.{ }^{2} \mathrm{H}\right] \mathrm{NADPH}$ confirm that the C4-pro- $R$-hydride from the nicotinamide ring is transferred to the FAD. The latter experimental result suggests that the nicotinamide ring rotates within the active site to carry out its two functional roles: reduction of the FAD cofactor and stabilization of the C4a-peroxyflavin adduct.
\end{abstract}

Keywords: Bayer-Villiger monooxygenase, Acetone monooxygenase, Stopped-flow spectroscopy

\section{Introduction}

Baeyer-Villiger monooxygenases (BVMOs) are flavincontaining enzymes that oxidize ketones to esters or lactones, using $\mathrm{O}_{2}$ and reducing equivalents from $\mathrm{NAD}(\mathrm{P})$ $\mathrm{H}$. They hold promise as versatile biocatalysts given their broad substrate scope and excellent enantio-, and regioselectivity (Leisch et al. 2011; Torres Pazmino et al. 2010). In addition to Baeyer-Villiger oxidations, BVMOs can also oxidize a range of other functional groups including aldehydes, sulfides, amines, phosphines, and selenides and iodide containing molecules (de Gonzalo et al. 2010; Balke et al. 2012; Rehdorf et al. 2009). The majority of BVMOs are type I BVMOs, which bind FAD, elicit a high preference for NADPH, and are composed of a single polypeptide. The substrate scope and catalytic promiscuity varies greatly among the enzyme family. For

\footnotetext{
*Correspondence: kirsten.wolthers@ubc.ca

${ }^{1}$ Department of Chemistry, University at the British Columbia, Okanagan

Campus, 3247 University Way, Kelowna, BC V1V 1V7, Canada

Full list of author information is available at the end of the article
}

example, some BVMOs act on bulky steroids, sesquiterpenes or aflatoxins, while the substrate scope of others is limited to smaller (a)cyclic ketones (Kolek et al. 2008).

The BVMO catalytic mechanism was formulated from kinetic and spectroscopic analysis of cyclohexanone monooxygenase (CHMO) from Acinetobacter sp. NCIMB 9871, one of the more comprehensively studied members of the enzyme family (Scheme 1) (Ryerson et al. 1982; Sheng et al. 2001). Following reduction of oxidized FAD by NADPH, the resulting $\mathrm{FADH}^{-}$reacts with $\mathrm{O}_{2}$ to form the C4a-peroxyflavin adduct. In BVMO, the prolonged lifetime of this intermediate is partially attributed to $\mathrm{NADP}^{+}$, which remains situated in the active site and is the final product to dissociate from the enzyme. If the enzyme undergoes productive catalysis (i.e. performs a monooxygenation reaction), then the C4a-peroxyflavin adduct attacks the carbonyl group of the ketone substrate, leading to formation of a tetrahedral Criegee intermediate which then collapses to form the lactone and hydroxyflavin intermediate. Release of water from hydroxyflavin returns the FAD cofactor to its oxidized 


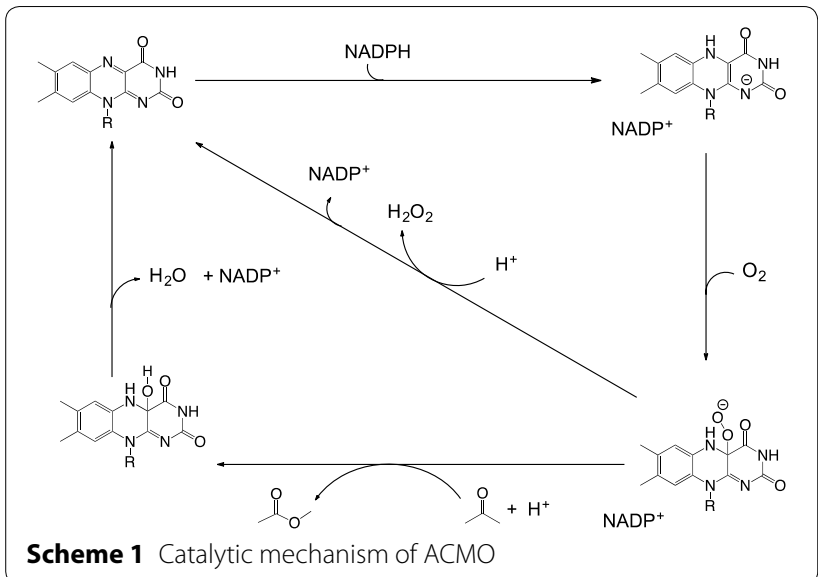

state for another catalytic cycle. In the absence of substrate, the C4a-peroxyflavin adduct can become protonated and collapse to form $\mathrm{H}_{2} \mathrm{O}_{2}$, leading to uncoupled NADPH oxidation.

Acetone monooxygenase (ACMO) is an example of a Type I BVMO that functions in the catabolism of small organic ketones. The enzyme was initially isolated from Gordonia sp. strain TY-5, a Gram-positive bacterium capable of aerobic growth with gaseous propane as the sole carbon source (Hausinger 2007). The bacterium encodes an $\mathrm{NADH}$-dependent dinuclear-iron-containing multicomponent monooxygenase that converts propane to 2-propanol and three secondary alcohol dehydrogenases that oxidize 2-propanol to acetone. ACMO, encoded by the acmA gene is part of a bicistronic operon that also includes the $a c m B$ gene. ACMO was shown to convert acetone to methyl acetate, while the gene product of $a \mathrm{cmB}$, an esterase, hydrolyzes methyl acetate to methanol and acetate (Kotani et al. 2007).

$\mathrm{ACMO}$ appears to be unique among BVMOs based on its ability to act on acetone. More well studied BVMO family members such as CHMO and phenylacetone monooxygenase from Thermobifida fusca (PAMO) are not able to catalyze the oxidation of this smallest ketone (Fraaije et al. 2005; Donoghue et al. 1976). Our group was interested in examining AMCO's catalytic efficiency towards acetone to assess its potential to be used as a biosensor, for example in the detection of ketone bodies in the salvia of diabetics. Herein, we measured the enzyme's catalytic efficiency for acetone, relative to larger linear and cyclic ketones. The stability of the enzyme at various temperatures was also measured along with the $\mathrm{pH}$-dependence of its activity. Stopped-flow analysis of the reductive half reaction with $4(R)-\left[4-{ }^{2} \mathrm{H}\right] \mathrm{NADPH}$ supports transfer of the proR-hydrogen, while pre-steady state kinetic analysis of the oxidative half reaction reveals that the C4a-peroxyflavin intermediate is a less stable intermediate in ACMO. Finally molecular modeling revealed structural variation in the coenzyme binding pocket that results in weaker $\mathrm{NADP}(\mathrm{H})$ binding affinity.

\section{Materials and methods}

Materials

$\mathrm{NADPH}, \mathrm{NADP}^{+}$, ketone substrates, xanthine, xanthine oxidase, methyl viologen, and benzyl viologen were purchased from Sigma. Restriction enzymes were purchased from New England Biolabs, and PfuTurbo DNA polymerase was obtained from Agilent Technologies. All other chemicals and media were purchased from VWR. 4(R)$\left[4-{ }^{2} \mathrm{H}\right] \mathrm{NADPH}$ was synthesized and purified following a published protocol (Bowman et al. 2010).

\section{Construction of the ACMO expression vector}

The cDNA encoding ACMO was synthesized by GenScript (Piscataway, NJ, USA; GenBank Accession number MH880286).). The coding sequence was optimized for expression in E. coli and subcloned into pET23a $(+)$, which resulted in a C-terminal hexahistidine tag. This construct did not result in the overexpression of a soluble form of ACMO, so the opportunity was taken to subclone the ACMO cDNA into the pGEX4T1 vector, which places a glutathione $S$-transferase (GST) motif onto the $\mathrm{N}$-terminus of the protein. The forward $\left(5^{\prime}\right.$-CGG GAT CCA TGA GCA CGA CGA CGC TGG-3') and reverse (5'-CCG CTC GAG TTA CGA CAG TGC GAA ACC-3') primers used to amplify the ACMO coding sequence harbored BamHI and XhoI restriction enzyme sites (in bold), respectively. The CDNA for ACMO was PCR amplified using PfuTurbo DNA polymerase, digested with BamHI and XhoI and ligated into pGEX4T1 also cut with the same restriction enzymes. The resulting construct (pGEX-ACMO) was transformed into E. coli DH5 $\alpha$ for protein expression.

\section{Construction of $\mathrm{ACMO} \mathrm{H} 325 \mathrm{~K}$ and $\mathrm{A} 443 \mathrm{\Delta}$ variants}

The $\mathrm{H} 325 \mathrm{~K}$ and $\mathrm{A} 443 \Delta$ variants were constructed using the QuikChange II site-directed mutagenesis kit from Agilent Technologies using the pGEX-ACMO vector as a template. The forward and reverse primers used for the H325K substitution are as follows: $5^{\prime}$-GAT TAC GGC TTC GGT ACC AAA CGC GTG CCG CTG GAA AC-3' and 5'-GAT TAC GGC TTC GGT ACC TTT CGC GTG CCG CTG GAA AC-3'. The oligonucleotides for the deletion of A433 are $5^{\prime}$-CCG CTG GCT CCG AGC GCT CTG TCG AAT ATG-3' and 5'-CAT ATT GCA CAG AGC GCT CGG AGC CAG CGG-3'. The successful incorporation of lysine at position 325 , the deletion of A433, and the absence of any unintended sequence alterations was confirmed by DNA sequencing at the NAPS 
DNA Sequencing Laboratory at University of British Columbia, Vancouver, Canada.

\section{Expression and purification of $\mathrm{ACMO}$ and the $\mathrm{H} 325 \mathrm{~K}$ and $A 443 \Delta$ variants}

An overnight culture of DH5 $\alpha$ harbouring the pGEXACMO plasmid was used to inoculate six $1.5 \mathrm{~L}$ flasks of Terrific Broth supplemented with ampicillin $(100 \mu \mathrm{g} /$ $\mathrm{mL}$ ). Cultures were grown at $30{ }^{\circ} \mathrm{C}$ with agitation, set at $200 \mathrm{rpm}$, to an $\mathrm{OD}_{600}$ of 0.8 . Recombinant protein expression was induced with the addition of $0.2 \mathrm{mM}$ of IPTG to the cell cultures. Following continued growth at $25^{\circ} \mathrm{C}$ for $16 \mathrm{~h}$, the cells were harvested by centrifugation $(6000 \times g$ for $15 \mathrm{~min})$. The cell pellet was frozen at $-80^{\circ} \mathrm{C}$ until purification.

All purification steps were performed on ice or at $4{ }^{\circ} \mathrm{C}$. The frozen cell pellet $(\sim 25 \mathrm{~g})$ was resuspended in $200 \mathrm{~mL}$ of GST bind/wash buffer $\left(10 \mathrm{mM} \mathrm{Na} 2 \mathrm{HPO}_{4}, 1.8 \mathrm{mM}\right.$ $\mathrm{KH}_{2} \mathrm{PO}_{4}, 0.14 \mathrm{M} \mathrm{NaCl}, 2.7 \mathrm{mM} \mathrm{KCl}, 1 \mathrm{mM}$ EDTA, $1 \mathrm{mM}$ DTT, pH 7.5) containing $10 \mu \mathrm{g} / \mathrm{mL}$ of benzamidine and $1 \mathrm{mM}$ phenylmethylsulfonyl fluoride. The cells were lysed and the genomic DNA was sheared by sonication and then the cell suspension was centrifuged $(38,000 \times g$ for $60 \mathrm{~min}$ ). The clarified cell extract was applied to a $5.5 \times 4.0 \mathrm{~cm}$ column containing glutathione Sepharose 4B (GE Healthcare Life Sciences) equilibrated with GST bind/wash buffer. The column was washed with 1 L ( $\sim 10$ column volumes) of GST bind/wash buffer. The GSTACMO chimera was eluted with $50 \mathrm{mM}$ Tris- $\mathrm{HCl}$, $\mathrm{pH} 8.0$ supplemented with $1 \mathrm{mM}$ dithiothreitol and $10 \mathrm{mM}$ glutathione. The eluate was dialyzed against $4 \mathrm{~L}$ of GST bind/wash buffer containing $1 \mathrm{mM}$ EDTA and $1 \mathrm{mM}$ dithiothreitol for $16 \mathrm{~h}$ with thrombin to cleave the GST tag. To separate ACMO from the uncut GSTACMO chimera and thrombin, the dialyzed protein was applied to a glutathione Sepharose $4 \mathrm{~B}(2.5 \times 3.0 \mathrm{~cm})$ column equilibrated with GST bind/wash buffer. The column was then washed with $50 \mathrm{~mL}$ of the GST bind/wash buffer with $10 \%$ glycerol $(\mathrm{v} / \mathrm{v})$. The yellow fractions were collected and the protein was concentrated using a centrifugal concentrator with a $30 \mathrm{kDa}$ cutoff filter. ACMO was then applied to a Q-Sepharose column $(2.6 \times 14 \mathrm{~cm})$ equilibrated with buffer A (50 mM Tris- $\mathrm{HCl} \mathrm{pH} 7.5,10 \%$ glycerol). The protein was eluted with a linear gradient to $50 \mathrm{mM}$ Tris- $\mathrm{HCl} \mathrm{pH} \mathrm{7.5,10 \%} \mathrm{glycerol,} 0.5 \mathrm{M} \mathrm{NaCl}$. The eluted protein was concentrated and stored at $-80{ }^{\circ} \mathrm{C}$ in $20 \%$ glycerol (v/v).

\section{Determining the molar absorption coefficient of ACMO}

The UV-visible absorbance spectrum of ACMO was recorded between 700 and $200 \mathrm{~nm}$ in $50 \mathrm{mM}$ HEPES $\mathrm{pH}$ 7.5 at $25{ }^{\circ} \mathrm{C}$. The flavoprotein $(1.2 \mathrm{~mL})$ was then added to $0.3 \mathrm{~mL}$ of a $10 \%$ solution of SDS to obtain a final concentration of $0.2 \%$ SDS. Changes in the spectra of the flavin cofactor were recorded at $4 \mathrm{~min}$ intervals until a constant absorbance spectrum was obtained. The protein solution was then centrifuged at 14,000 rpm for $10 \mathrm{~min}$ in a microcentrifuge and the spectrum of the FAD liberated from the protein was measured. The concentration of free FAD released from the protein was calculated using a molar absorptivity of free $\operatorname{FAD}\left(\varepsilon_{450}=11,300 \mathrm{M}^{-1} \mathrm{~cm}^{-1}\right)$. The molar absorption coefficient of ACMO was calculated to be $\varepsilon_{443}=12,200 \mathrm{M}^{-1} \mathrm{~cm}^{-1}$ after correcting for the dilution of the protein.

\section{$\mathrm{NADP}^{+}$binding constant determination}

UV-visible absorbance spectroscopy was used to determine the equilibrium dissociation constant for $\mathrm{NADP}^{+}$. The assays were performed on a Perkin Elmer Lambda 25 UV-visible spectrophotometer in 50 mM HEPES pH 7.5 at $25{ }^{\circ} \mathrm{C}$. $\mathrm{NADP}^{+}$was sequentially added to an absorbance cuvette containing $50 \mu \mathrm{M}$ of flavoprotein, achieving $\mathrm{NADP}^{+}$concentrations ranging from 0 to $200 \mu \mathrm{M}$. The change in absorbance at a given wavelength was fit to the quadratic binding isotherm (Eq. 1).

$$
\Delta A=\left(\frac{\Delta A_{\max }}{2 E_{o}}\right)\left\{E_{o}+L_{o}+K_{d}-\left[\left(E_{o}+L_{O}+K_{d}\right)^{2}-4 E_{o} L_{o}\right]^{1 / 2}\right\}
$$

where $\mathrm{L}_{o}$ is total $\mathrm{NADP}^{+}$concentration; $E_{o}$ is total enzyme concentration; $\Delta A$ is the change in absorbance, $\Delta A_{\max }$ is the maximum change in absorbance; and $K_{\mathrm{d}}$ is the dissociation constant for the GSTACMO-NADP ${ }^{+}$ complex.

\section{Determining the reduction potential of GSTACMO}

The reduction potential of GSTACMO was determined by Massey's method (Massey 1991). The method relies on the near simultaneous reduction of GSTACMO and a reference dye with a known reduction potential by reducing equivalents derived from xanthine oxidase and xanthine. The reference dye used in the GSTACMO reduction was indigo disulfonate, which has a reduction potential of $E_{\mathrm{m}}^{0}=-116 \mathrm{mV}$ at $\mathrm{pH}$ 7.0. The titration of GSTACMO was performed at $25{ }^{\circ} \mathrm{C}$ in a total volume of $1 \mathrm{~mL}$ in an anaerobically maintained glove box in 50 mM HEPES, $\mathrm{pH}$ 7.0, that was made anaerobic by the same method described for the stopped-flow experiments. A concentrated $2 \mathrm{~mL}$ stock of GSTACMO $(36 \mu \mathrm{M})$ was introduced into the glove box and gel filtered over a $10 \mathrm{~mL}$ PD10 column (Bio-Rad) equilibrated with anaerobic buffer (50 mM HEPES, pH 7.0). Stock solutions of benzyl viologen, indigo disulfonate, xanthine and xanthine oxidase were prepared by dissolving lyophilized powders of each in anaerobic buffer in the glove box. The reaction contained $20 \mu \mathrm{M}$ GSTACMO, $20 \mu \mathrm{M}$ indigo disulfonate, 
$0.5 \mathrm{mM}$ xanthine, and $5 \mu \mathrm{M}$ benzyl viologen. Following the addition of $0.25 \mu \mathrm{M}$ xanthine oxidase, the reaction mixture was placed in a Lambda 265 spectrophotometer (Perkin Elmer) also housed in the glove box, and reduction of the enzyme and dye was monitored over $2 \mathrm{~h}$ by recording the absorption spectrum of the reaction mixture every minute. The concentrations of the oxidized and reduced enzyme ( $E_{\mathrm{ox}}$ and $\left.E_{\mathrm{red}}\right)$ throughout the titration were determined at $458 \mathrm{~nm}$ (the isosbestic point of indigo disulfonate), while the concentration of the dye (both the oxidized and reduced forms; $D_{\text {ox }}$ and $D_{\text {red }}$ ) was determined at $610 \mathrm{~nm}$, where oxidized and hydroquinone forms of the FAD cofactor do not absorb. The reduction potential of the enzyme $\left(E_{\mathrm{e}}\right)$ and the dye $\left(D_{\mathrm{d}}\right)$ were calculated from the following equations:

$$
\begin{aligned}
& E_{e}=E_{e}^{\circ}-\frac{0.0592}{n_{e}} \log \left(\frac{E_{r e d}}{E_{o x}}\right) \\
& E_{d}=E_{d}^{\circ}-\frac{0.0592}{n_{d}} \log \left(\frac{D_{r e d}}{D_{o x}}\right)
\end{aligned}
$$

where $n$ is the number of electrons. At equilibrium, $E_{\mathrm{d}}$ is equal to $E_{\mathrm{e}}$ and Eqs. 1 and 2 can be rearranged to the following equation:

$$
\log \left(\frac{E_{r e d}}{E_{o x}}\right)=\frac{n_{e}\left(E_{e}^{\circ}-E_{d}^{\circ}\right)}{0.0592}+\left(\frac{n_{e}}{n_{d}}\right) \log \left(\frac{D_{\text {red }}}{D_{o x}}\right)
$$

Equation 3 enables the reduction potential of GSTACMO, $E_{e}^{\circ}$ to be determined from the y-intercept of a plot of $\log \left(E_{\text {red }} / E_{\text {ox }}\right)$ versus $\log \left(D_{\text {red }} / \mathrm{D}_{\text {ox }}\right)$.

\section{Steady-state kinetic assays}

The steady-state parameters of ACMO and GSTACMO were determined for a variety of linear and cyclic ketones by following the rate of oxidation of NADPH at $340 \mathrm{~nm}$ $\left(\Delta \varepsilon_{340}=6.22 \mathrm{mM}^{-1} \mathrm{~cm}^{-1}\right)$. The reactions were performed in a total volume of $1 \mathrm{~mL}$ in air-saturated $50 \mathrm{mM}$ HEPES buffer, $\mathrm{pH} 7.5$ at $25{ }^{\circ} \mathrm{C}$ using a Lambda $25 \mathrm{UV}-$ visible spectrophotometer (Perkin Elmer) placed on the laboratory bench. The steady-state kinetic parameters were determined by measuring the initial velocity for the oxidation of various ketones in $1 \mathrm{~mL}$ reaction mixtures that contained $100 \mu \mathrm{M} \mathrm{NADPH}$ and variable concentrations $(0.1-5 \mathrm{mM})$ of the ketone substrate. The Michaelis constant for NADPH was determined with variable concentrations of NADPH and a fixed concentration of butanone $(200 \mu \mathrm{M})$. All steady-state reactions were initiated with $23-45 \mathrm{nM}$ of ACMO or GSTACMO. The initial velocities were plotted as a function of substrate concentration and fitted to the Michealis Menten equation using nonlinear least squares analysis with the computer program Origin 8.0 (OriginLab). The NADP ${ }^{+}$ inhibition assays were performed with variable $\mathrm{NADP}^{+}$ $(0-1 \mathrm{mM})$ and NADPH $(0.2-100 \mu \mathrm{M})$ concentrations in the presence of $200 \mu \mathrm{M}$ butanone. The inhibition data were fitted to the competitive inhibition equation using Origin 8.0. The rate of uncoupled NADPH oxidation was determined by measuring absorbance changes at $340 \mathrm{~nm}$ in the presence of $100 \mu \mathrm{M}$ NADPH and in the absence of a ketone substrate.

\section{Stability assays and $\mathrm{pH}$-dependence}

The thermostability of GSTACMO was analyzed by incubating the purified enzyme $(0.5 \mu \mathrm{M})$ at a set temperature (ranging from 5 to $45^{\circ} \mathrm{C}$ ) for $1 \mathrm{~h}$ in $50 \mathrm{mM}$ HEPES, $\mathrm{pH}$ 7.5. After incubation the samples were placed on ice and then measured for activity by following the rate of $\mathrm{NADPH}$ oxidation spectrophotometrically at $340 \mathrm{~nm}$. Residual activity was measured at $25{ }^{\circ} \mathrm{C}$ in $50 \mathrm{mM}$ HEPES, pH 7.5 containing $100 \mu \mathrm{M}$ NADPH and $200 \mu \mathrm{M}$ butanone. The reactions were initiated with the addition of $25 \mathrm{nM}$ GSTACMO. The activity of GSTACMO was measured at a range of $\mathrm{pH}$ values (5.5-9.0) using a three-component buffer containing $50 \mathrm{mM}$ each of MES, HEPES and CHES. Each $1 \mathrm{~mL}$ contained $100 \mu \mathrm{M}$ $\mathrm{NADPH}, 200 \mu \mathrm{M}$ butanone and $50 \mathrm{nM}$ of GSTACMO. The bell-shaped $\mathrm{pH}$ profiles where catalysis requires the ionization of a group with a low $\mathrm{p} K_{\mathrm{a}}$ and the protonation of a group having a higher $\mathrm{p} K_{\mathrm{a}}$ were fit to the equation:

$$
\log Y=\log \left[\frac{Y_{H}}{1+H / K_{a 2}+K_{a 1} / H}\right]
$$

where $Y$ is the observed velocity, $Y_{\mathrm{H}}$ is the velocity when both ionizable groups are in their preferred ionization state for maximal activity, and $K_{\mathrm{a} 1}$ and $K_{\mathrm{a} 2}$ are the dissociation constants for the groups that ionize at low and high $\mathrm{pH}$, respectively. The activity at each $\mathrm{pH}$ and temperature was measured in triplicate.

\section{Pre-steady state kinetics}

Pre-steady state kinetic assays were performed under anaerobic conditions using a SF-61DX2 stopped-flow apparatus (TgK Scientific). The sample-handling unit of the stopped-flow is housed in a glove box (Belle Technology) with $\mathrm{O}_{2}$ concentration $<5 \mathrm{ppm}$. The reductive and oxidative half reactions were performed at $25{ }^{\circ} \mathrm{C}$ in 50 mM HEPES, pH 7.5 with $20 \%$ glycerol. The buffer was made anaerobic by purging with nitrogen gas for $2 \mathrm{~h}$ followed by a $16 \mathrm{~h}$ equilibration in the glove box. Stock solutions of NADPH and $\mathrm{NADP}^{+}$were prepared by dissolving lyophilized powders of the coenzyme in anaerobic 
buffer. The enzyme was diluted to the appropriate concentration with anaerobic buffer. The reductive-half reaction (following NADPH-dependent reduction of oxidized GSTACMO) was monitored by rapidly mixing the oxidized enzyme with an equal volume of NADPH at a concentration that was at a minimum sevenfold higher than the protein concentration so as to maintain pseudo-first order conditions. Changes in the flavin absorbance spectra were monitored at $443 \mathrm{~nm}$ using a photomultiplier and the absorbance traces were fitted to a single exponential equation using Kinetic Studio (TgK Scientific). The concentration of the protein and cofactors were each diluted twofold in the observation cell. The NADPH concentration dependence profiles were fit to the following hyperbolic equation:

$$
k_{o b s}=\frac{k_{r e d}[N A D P H]}{K_{d}+[N A D P H]}
$$

where $k_{\text {red }}$ is the limiting rate constant of flavin reduction and $K_{\mathrm{d}}$ is the dissociation constant for NADPH.

The oxidative half-reaction was monitored under NADPH uncoupling conditions (in the absence of ketone substrate) and under normal turnover conditions (in the presence of butanone). In the first experiment, an anaerobic solution of GSTACMO $(20 \mu \mathrm{M})$ was reduced with the addition of an equimolar amount of NADPH. NADP ${ }^{+}$(at a final concentration of $500 \mu \mathrm{M}$ ) was added to the prereduced enzyme and then this solution was rapidly mixed with an equal volume of air-saturated $50 \mathrm{mM}$ HEPES $\mathrm{pH}$ $7.5,20 \%$ glycerol. The second experiment was performed under the same conditions except that $400 \mu \mathrm{M}$ butanone was added to the aerated buffer. Butanone was chosen as a substrate as it elicited the highest catalytic efficiency for ACMO. Changes in the flavin spectra were monitored at multiple wavelengths using a photodiode array detector or at individual wavelengths with a photomultipier. Typically, five absorbance traces in single wavelength mode were fitted to a standard single or double exponential equation to extract the observed rate constants.

\section{Results}

\section{Purification and spectral characterization of ACMO}

Recombinant ACMO was expressed as a GST fusion protein, which enabled the first purification step to involve glutathione affinity chromatography. The GSTtag appeared to stabilize the flavoprotein as removal of the tag following thrombin cleavage caused the protein to slowly precipitate in $50 \mathrm{mM}$ Tris- $\mathrm{HCl}, \mathrm{pH} 7.5$ at $4{ }^{\circ} \mathrm{C}$. To prevent precipitation, glycerol $(10 \% \mathrm{v} / \mathrm{v})$ was added to the flavoenzyme prior to loading on to the Q-Sepharose column. Following elution from the Q-Sepharose column, the protein was shown to have a molecular mass of $\sim 60 \mathrm{kDa}$ (close to the calculated molecular mass of $59,780 \mathrm{Da}$ ) and was $90 \%$ homogeneous, as deduced from a Coomassie Blue stained SDS-PAGE gel (Additional file 1: Fig. S1). Approximately, $10 \mathrm{mg}$ of protein was obtained from $1 \mathrm{~L}$ of bacterial culture. The UV-visible absorbance spectrum of ACMO showed absorbance maxima at 380 and $443 \mathrm{~nm}$, typical of flavins and flavoproteins (Fig. 1). Release of the FAD cofactor from $\mathrm{ACMO}$ in the presence of $0.2 \% \mathrm{SDS}$, enabled the extinction coefficient of ACMO $\left(\varepsilon_{443 \mathrm{~nm}}=12,200 \pm 490 \mathrm{M}^{-1} \mathrm{~cm}\right.$ ${ }^{-1}$ ) to be calculated from the known extinction coefficient of free FAD.

\section{Steady state assays}

The steady state kinetic parameters of ACMO were determined in $50 \mathrm{mM}$ HEPES, $\mathrm{pH} 7.5$ at $25^{\circ} \mathrm{C}$ for a number of linear and cyclic ketones (Table 1). The rate of $\mathrm{NADPH}$ oxidation (measured by the absorbance change at $340 \mathrm{~nm}$ ) in the presence of various ketones was used to access the enzyme's substrate scope. It has been reported for PAMO and CHMO that either release of $\mathrm{NADP}^{+}$or dehydration of the C4a-hydroxyflavin is the rate-determining step in catalysis, not oxidation of the ketone substrate (Sheng et al. 2001; Torres Pazmino et al. 2008). As a result these enzymes elicit similar turnover numbers with a broad selection of substrates (Donoghue et al. 1976; Mascotti et al. 2013, 2014). We observe a similar phenomenon with ACMO, as Table 1 shows that the enzyme exhibits narrow range of $k_{\text {cat }}$ values $\left(1.4-4.3 \mathrm{~s}^{-1}\right)$ for a variety of ketone substrates, indicating that like other BVMOs, oxygen insertion into the substrate is not the rate-determining step of catalysis. As shown in Table 1, ACMO elicits low $K_{\mathrm{m}}$ values (and correspondingly high $k_{\text {cat }} / K_{\mathrm{m}}$ values) for small (a)cyclic ketones like butanone and cyclic butanone. The exception is acetone, which had

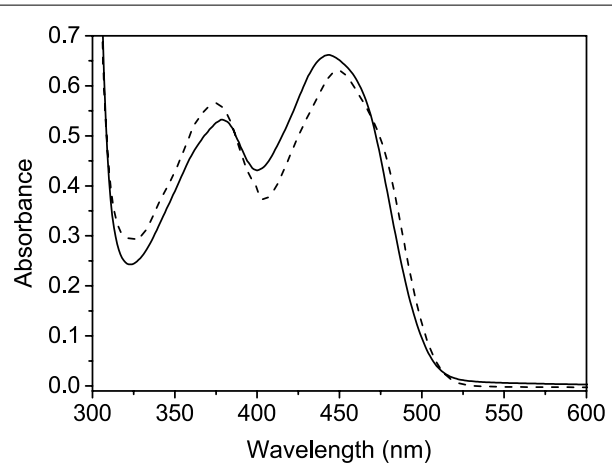

Fig. 1 UV-visible absorbance spectra of ACMO showing the diagnostic flavin peaks at 380 and $440 \mathrm{~nm}$. The black line denotes the spectrum of ACMO while the dashed line is the released FAD cofactor following incubation of $\mathrm{ACMO}$ in $0.2 \% \mathrm{SDS}$ for $10 \mathrm{~min}$ at $25^{\circ} \mathrm{C}$ in 50 mM HEPES-NaOH pH 7.5 
Table 1 Steady-state kinetic parameters of ACMO and GSTACMO

\begin{tabular}{|c|c|c|c|c|}
\hline Enzyme & Variable substrate & $k_{\text {cat }}\left(\mathrm{s}^{-1}\right)$ & $K_{\mathrm{m}}(\mu \mathrm{M})$ & $k_{\mathrm{cat}} / K_{\mathrm{m}}\left(\mathrm{M}^{-1} \mathrm{~s}^{-1}\right) \times 10^{3}$ \\
\hline $\mathrm{ACMO}$ & $\mathrm{NADPH}$ & $2.0 \pm 0.1$ & $6.7 \pm 0.8$ & $300 \pm 36$ \\
\hline $\mathrm{ACMO}$ & Acetone & $1.4 \pm 0.2$ & $170 \pm 11$ & $8.5 \pm 0.59$ \\
\hline $\mathrm{ACMO}$ & Butanone & $2.1 \pm 0.1$ & $0.34 \pm 0.03$ & $6000 \pm 550$ \\
\hline $\mathrm{ACMO}$ & 2-Pentanone & $1.9 \pm 0.1$ & $0.37 \pm 0.06$ & $4800 \pm 760$ \\
\hline $\mathrm{ACMO}$ & 2-Heptanone & $3.9 \pm 0.1$ & $1.5 \pm 0.1$ & $2600 \pm 130$ \\
\hline $\mathrm{ACMO}$ & 3-Methylbutanone & $2.2 \pm 0.1$ & $4.4 \pm 0.5$ & $510 \pm 55$ \\
\hline $\mathrm{ACMO}$ & 2,4-Dimethyl-3-pentanone & $1.5 \pm 0.1$ & $1500 \pm 220$ & $1.0 \pm 0.15$ \\
\hline ACMO & Cyclobutanone & $2.0 \pm 0.1$ & $1.5 \pm 0.2$ & $1400 \pm 190$ \\
\hline $\mathrm{ACMO}$ & Cyclopentanone & $4.3 \pm 0.1$ & $120 \pm 11$ & $35 \pm 3.2$ \\
\hline $\mathrm{ACMO}$ & Cyclohexanone & $3.6 \pm 0.2$ & $2400 \pm 400$ & $1.5 \pm 0.3$ \\
\hline ACMO & Bicyclo[3.2.0]hept-2-en-6-one & $1.5 \pm 0.1$ & $6.7 \pm 1.3$ & $220 \pm 45$ \\
\hline $\mathrm{ACMO}$ & Phenylacetone & $1.0 \pm 0.1$ & $8.9 \pm 1.5$ & $112 \pm 20$ \\
\hline GSTACMO & Cyclohexanone & $2.8 \pm 0.1$ & $2300 \pm 380$ & $1.2 \pm 0.2$ \\
\hline H325K & $\mathrm{NADPH}$ & $1.6 \pm 0.1$ & $0.48 \pm 0.05$ & $3250 \pm 320$ \\
\hline H325K & Butanone & $1.6 \pm 0.1$ & $0.48 \pm 0.05$ & $3250 \pm 320$ \\
\hline
\end{tabular}

The experiments were performed in $50 \mathrm{mM} \mathrm{HEPES}-\mathrm{NaOH}$ pH 7.5 at $25^{\circ} \mathrm{C}$ as described in "Materials and methods". Butanone was present at a fixed saturating concentration of $200 \mu \mathrm{M}$ in steady-state experiments where NADPH served as the variable substrate. For experiments where the ketone served as the variable substrate, NADPH was present at $100 \mu \mathrm{M}$

a 500-fold higher $K_{\mathrm{m}}$ and a 700 -fold lower $k_{\text {cat }} / K_{\mathrm{m}}$ compared to butanone. For the acyclic ketones, lengthening of the chain or branching of the substrate with the addition of methyl groups resulted in an increase in the $K_{\mathrm{m}}$, suggesting that these bulkier substrates bind more weakly to the enzyme. Likewise, a progressive increase in the size of the ring of the cyclic ketone led to a gradual increase in $K_{\mathrm{m}}$ and a decrease in $k_{\text {cat }} / K_{\mathrm{m}}$. ACMO exhibited no activity towards cycloheptanone. However, ACMO did show activity for phenylacetone and bicyclo[3.2.0] hept-2-en-6-one.

The rate of uncoupled NADPH oxidation was relatively high at $0.26 \mathrm{~s}^{-1}, \sim$ tenfold lower than that observed in the presence of saturating amounts of the ketone substrate (Table 2). By comparison, the rate of uncoupled NADPH oxidation in PAMO is $0.02 \mathrm{~s}^{-1}$ (Torres Pazmino et al. 2008). The relatively high rate of NADPH oxidase activity for ACMO suggests that the C4a-peroxyflavin is less stable in this enzyme and more prone to decay to $\mathrm{H}_{2} \mathrm{O}_{2}$. The Michaelis constant $\left(K_{\mathrm{m}}\right)$ for NADPH, determined in the presence of $200 \mu \mathrm{M}$ butanone was $6.7 \pm 0.8 \mu \mathrm{M}$. ACMO is highly specific for NADPH as no activity was detected with $\mathrm{NADH}$ as the reductant. $\mathrm{NADP}^{+}$was found to be a poor competitive inhibitor of ACMO with a $K_{\mathrm{i}}$ of $166 \pm 13 \mu \mathrm{M}$. By comparison, PAMO and CHMO elicit $K_{\mathrm{i}}$ values of $2.7 \mu \mathrm{M}$ and $35 \mu \mathrm{M}$, respectively, for the oxidized coenzyme (Ryerson et al. 1982; Torres Pazmino et al. 2008). Finally, the GST tag does not appear to adversely affect the kinetic behavior of the enzyme as GSTACMO (ACMO with a fused N-terminal GST tag)
Table 2 Additional kinetic parameters for ACMO

\begin{tabular}{lll}
\hline Enzyme & Parameters & Measured values \\
\hline $\mathrm{ACMO}$ & $K_{\mathrm{I}(\mathrm{NADP}+)}$ & $166 \pm 13 \mu \mathrm{M}$ \\
$\mathrm{H} 325 \mathrm{~K}$ & $K_{\mathrm{I}(\mathrm{NADP}+)}$ & $27 \pm 6 \mu \mathrm{M}$ \\
$\mathrm{ACMO}$ & $K_{\text {unc }}\left(\mathrm{s}^{-1}\right)$ & $0.26 \pm 0.02 \mathrm{~s}^{-1}$ \\
$\mathrm{ACMO}$ & $K_{\text {red }}\left(\mathrm{s}^{-1}\right)$ & $59 \pm 3 \mathrm{~s}^{-1}$ \\
$\mathrm{ACMO}$ & $K_{\mathrm{d}(\mathrm{NADPH})}$ & $120 \pm 14 \mu \mathrm{M}$ \\
\hline
\end{tabular}

The inhibition constant for $\mathrm{NADP}^{+}, \mathrm{K}_{\mathrm{i}(\mathrm{NADP}+)}$ was determined in the presence of $200 \mu \mathrm{M}$ butanone. The turnover rates for uncoupled NADPH oxidation $\left(k_{\text {unc }}\right)$ were measured with $100 \mu \mathrm{M}$ NADPH. The limiting rate constant for NADPHdependent flavin reduction $\left(k_{\text {red }}\right)$ and the dissociation constant for NADPH $\left(K_{\mathrm{d}(\mathrm{NADPH})}\right)$ were determined by fitting Eq. 6 to the data shown in Fig. 4a. All reactions were performed at $25^{\circ} \mathrm{C}$ in $50 \mathrm{mM}$ HEPES-NaOH, pH 7.5

elicited similar $k_{\text {cat }}$ and $K_{\mathrm{m}}$ with cyclohexanone compared to ACMO. Given that chimeric protein elicits similar steady state kinetic properties as $\mathrm{ACMO}$ and is more stable, subsequent kinetic, thermodynamic and binding studies described below were performed on GSTACMO.

\section{Molecular modelling}

To structurally rationalize the low $\mathrm{NADP}^{+}$binding affinity we performed a sequence alignment of ACMO with related BVMOs and constructed a homology model of ACMO using MODELLER (version 9.20; Webb and Sali 2014). The model was created using a C65D variant of PAMO as a template (PDB entry $4 \mathrm{~d} 03$ ), which shares $43 \%$ sequence identity with ACMO. The sequence alignment and ACMO model revealed sequence variation in the 
coenzyme binding cleft (Fig. 2). Typically, a lysine residue interacts with the $2^{\prime}$-phosphate of $\mathrm{NADP}(\mathrm{H})$ in BVMOs. This noncovalent interaction has been shown to improve the binding affinity for the coenzyme in addition to the enzyme's preference for NADPH over NADH (Kamerbeek et al. 2004). In ACMO, a histidine residue ( $\mathrm{His}^{325}$ ) replaces the lysine, a substitution that could potentially weaken the electrostatic interaction between the $2^{\prime}$ phosphate of the coenzyme and the protein. To test this hypothesis, $\mathrm{His}^{325}$ was substituted for a lysine. As shown in Tables 1 and 2, the H325K substitution lead to a significant improvement in coenzyme binding affinity as evidenced by the sixfold decrease in the $K_{\mathrm{m}}$ for NADPH and a 14-fold decrease in $K_{\mathrm{i}}$ for $\mathrm{NADP}^{+}$. The modeling exercise also revealed the insertion of an alanine (A433) in an active site bulge that has been shown to restrict the substrate scope of PAMO (Bocola et al. 2005; Reetz and Wu 2008). Deletion of this residue in ACMO led to a 130 -fold decrease in the $k_{\mathrm{cat}} / K_{\mathrm{m}}$ for butanone, whilst the catalytic efficiency for cyclobutanone was unchanged. There was no increase in NADPH oxidation in the presence of acetone for this variant.

\section{$\mathrm{NADP}^{+}$binding affinity for GSTACMO}

The binding of $\mathrm{NADP}^{+}$to PAMO and $\mathrm{CHMO}$ has been shown to induce notable shifts in the flavin absorbance spectra. This absorbance shift is attributed to displacement of a highly conserved catalytic arginine residue by the $\mathrm{NADP}^{+}$nicotinamide ring as it docks over the xylene portion of the FAD isoalloxazine ring (Torres Pazmino et al. 2008; Sheng et al. 2001). In wild type CHMO and PAMO, binding of $\mathrm{NADP}^{+}$causes the absorbance peak at
383 to shift to $366 \mathrm{~nm}$ and the peak at $440 \mathrm{~nm}$ to develop a more prominent absorbance shoulder at $480 \mathrm{~nm}$. In GSTACMO, there is also a blue shift in the absorbance peak at $380 \mathrm{~nm}$ similar to that of related BVMOs (Fig. 3). However, in GSTACMO, the peak at $440 \mathrm{~nm}$ shifts to $450 \mathrm{~nm}$ with a sizable shoulder at $430 \mathrm{~nm}$. The distinct spectral shifts observed in GSTACMO are likely to due to minor structural variations in the active site induced by the binding of the oxidized coenzyme. To determine the binding affinity of the coenzyme, the absorbance change at $467 \mathrm{~nm}$ was plotted against the concentration of $\mathrm{NADP}^{+}$and the data were fitted to the equation describing the quadratic binding isotherm. For wild type GSTACMO, the dissociation constant for the GSTACMO-NADP $^{+}$complex was $21.1 \pm 4.1 \mu \mathrm{M}$ where as for the $\mathrm{H} 325 \mathrm{~K}$ variant it was $0.50 \pm 0.04 \mu \mathrm{M}$.

\section{Reduction potential of the ACMO flavin cofactor}

The reduction potential of the enzyme was determined by reducing GSTACMO in the presence of indigo disulfonate, which served as a reference dye. Figure 4a shows the combined spectra of the dye and GSTACMO following incubation with the xanithine/xanthine oxidase reducing system and the redox mediator benzyl viologen. The concentrations of the oxidized and reduced forms of the dye and GSTACMO were determined at 610 and $458 \mathrm{~nm}$, respectively, as described under "Materials and Methods". A plot of $\log \left(E_{\text {red }} / E_{\text {ox }}\right)$ versus $\log \left(D_{\text {red }} / D_{\text {ox }}\right)$ has a slope of 1.0, which indicates that an equal number of electrons (i.e. two) were transferred between GSTACMO and indigo disulfonate (Fig. $4 \mathrm{~b}$ ). The midpoint potential of GSTACMO calculated from the y-intercept of the

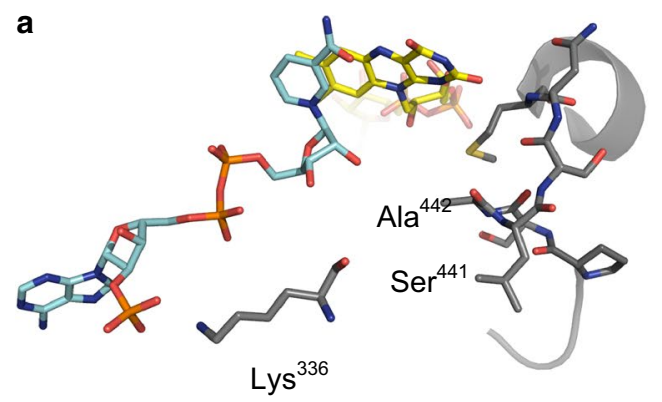

C

$\begin{array}{lll}\text { HAPMO } & 433 & \text { PDS-PVGGKRIVRD } \\ \text { CHMO } & 320 & \text { PQDL--YAKRPLCD } \\ \text { PAMO } & 328 & \text { PKGYPFGTKRLILE } \\ \text { ACMO } & 317 & \text { PSDYGFGTHRVPLE }\end{array}$

b

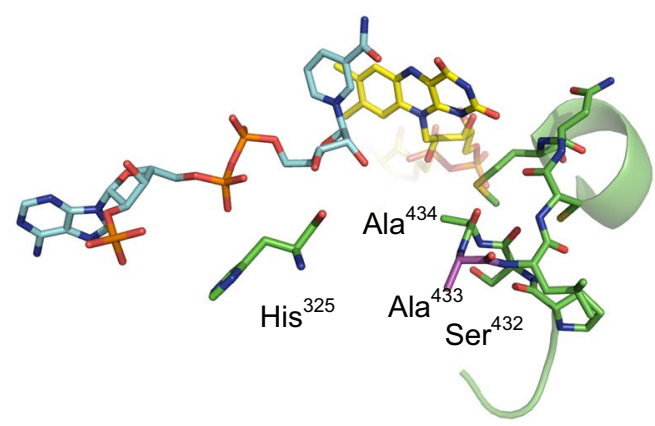

$\begin{array}{ll}427 & \text { GPNGP---FTNL } \\ 436 & \text { GPGSPS-ALSNM } \\ 426 & \text { VPLAPSAALCNM }\end{array}$

Fig. 2 Comparison of the crystal structure of PAMO (a, PDB entry $2 Y L R)$ and a homology model of ACMO (b) depicting distinct residues neighboring the $2^{\prime}$-phosphate of $\mathrm{NADP}^{+}$and the FAD and NADP+ are shown as stick models with the carbon atoms in yellow and cyan, respectively. $\mathbf{c}$ A sequence alignment of BVMOs showing variation in the active sites. Sequence variation in ACMO is highlighted in blue and red 

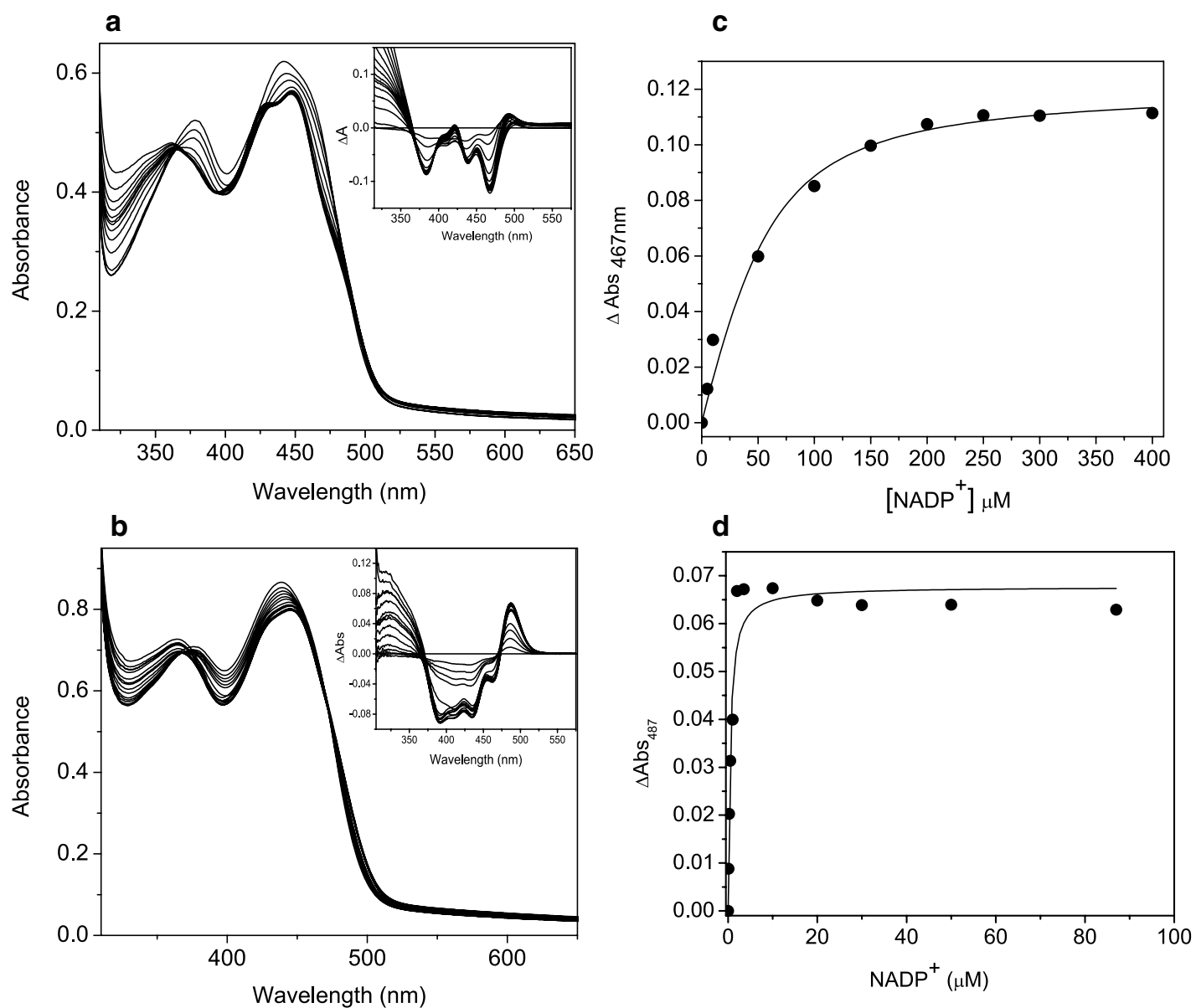

Fig. 3 Flavin absorption spectra of GSTACMO (a) and H325K (b) were recorded in 50 mM HEPES-NaOH pH 7.5 upon titration with NADP+ $(0-250 \mu \mathrm{M})$. The inset shows the difference spectra. Absorbance changes at $467 \mathrm{~nm}$ for wild type GSTACMO (c) and H325K (d) were plotted as a function of $\mathrm{NADP}^{+}$concentration and the data were fitted to a quadratic binding isotherm (Eq. 1), which gave $K_{\mathrm{d}}$ values of $21.1 \pm 4.1 \mu \mathrm{M}$ (wild type) and $0.50 \pm 0.04 \mu \mathrm{M}(\mathrm{H} 325 \mathrm{~K})$
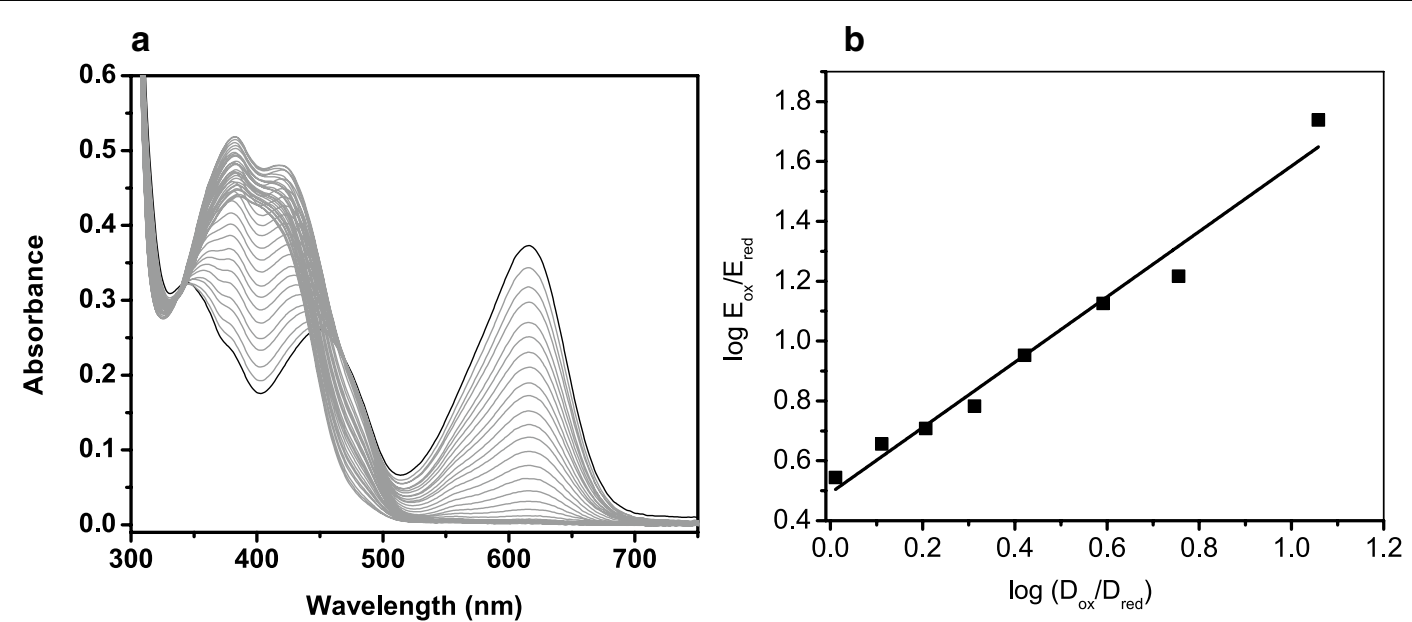

Fig. 4 Reduction potential measurement of GSTACMO. a The combined absorbance spectra of GSTACMO and indigo disulfonate as both species are slowly reduced with xanthine/xanthine oxidase. The standard reduction potential value of the enzyme $\left(E^{\circ}\right)$, calculated from the $y$-intercept of the plot of $\log \left(E_{\text {red }} / E_{\text {ox }}\right)$ versus $\log \left(D_{\text {red }} / D_{\text {ox }}\right)$ shown in $\mathbf{b}$, is $-166 \mathrm{mV} \pm 1 \mathrm{mV}$ 
graph is $-166 \pm 1 \mathrm{mV}$. Thus, GSTACMO is thermodynamically poised to accept a hydride ion from NADPH, which has a midpoint potential of $-320 \mathrm{mV}$.

\section{$\mathrm{pH}$-dependence and thermostability}

The thermostability of GSTACMO was measured by preincubating the enzyme at various temperatures $\left(5-45^{\circ} \mathrm{C}\right)$ for one hour and then measuring the residual activity at $25{ }^{\circ} \mathrm{C}$ (Fig. 5a). The enzyme elicited comparable residual activity at temperatures $\leq 20{ }^{\circ} \mathrm{C}$. However, incubation of the enzyme at temperatures $25^{\circ} \mathrm{C}$ and above resulted in $>60 \%$ loss of enzyme activity. These results demonstrate that GSTACMO is a relatively unstable protein. The pH-dependence profiles show a bell-shaped curve with maximal activity between $\mathrm{pH} 7$ and 8 (Fig. 5b). The $\mathrm{p} K_{\mathrm{a}}$ values of the ionizable groups responsible for optimal activity were determined by fitting the data to Eq. 5 . The fitting routine revealed that enzyme activity is dependent on protonation of a single ionizable group with of $\mathrm{p} K_{\mathrm{a}}$ of $5.6 \pm 0.2$ and ionization of group with a $\mathrm{p} K_{\mathrm{a}}$ of $9.2 \pm 0.3$.

\section{Reductive-half reaction}

The rate of NADPH-dependent reduction of GSTACMO was measured by following the absorbance decrease at $443 \mathrm{~nm}$ upon rapid mixing of the enzyme with a tenfold excess of coenzyme (Fig. 6a). The monophasic decay was fitted to a standard single exponential equation, which gave an observed rate constant $\left(k_{\text {obs }}\right)$ of $28.4 \pm 0.5 \mathrm{~s}^{-1}$. To confirm that this initial kinetic phase involved transfer of a hydride ion from NADPH to the FAD cofactor, the reaction was repeated with $4(R)-\left[4-{ }^{2} \mathrm{H}\right] \mathrm{NADPH}$. As shown in Fig. 6a, reduction of the enzyme with the deuterated coenzyme was significantly slower and a fit of the

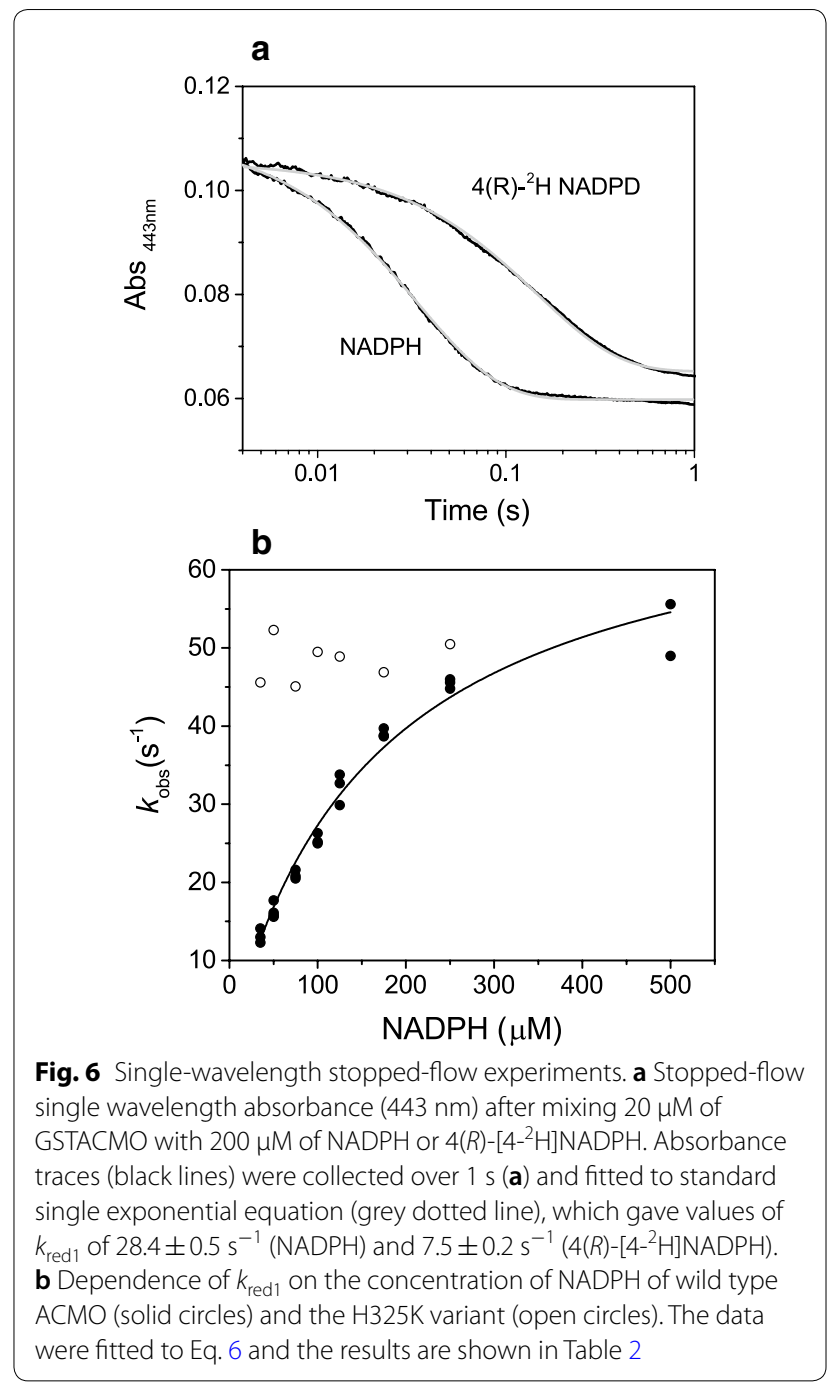

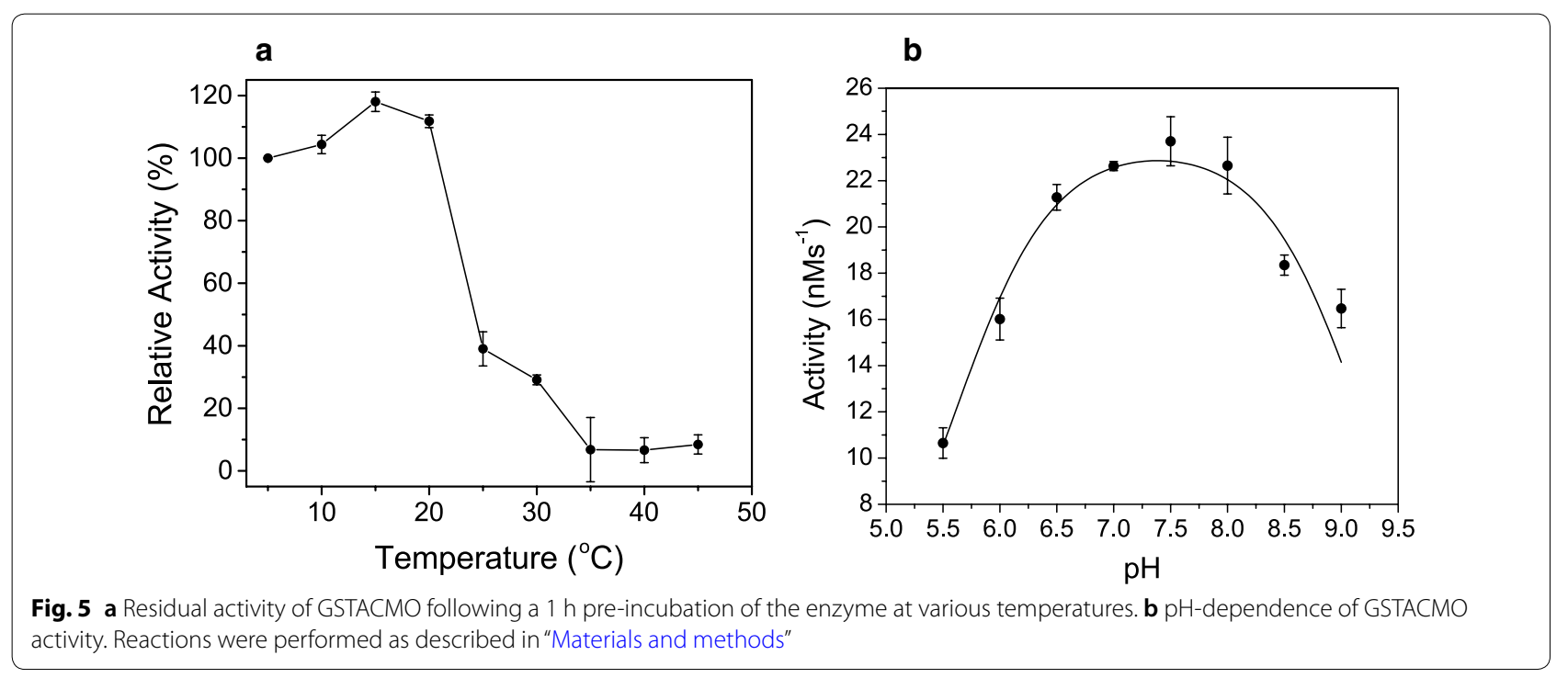


absorbance trace to a single exponential equation produced an observed rate constant of $7.5 \pm 0.2 \mathrm{~s}^{-1}$ and a kinetic isotope effect of $3.8 \pm 0.2$.

Single-wavelength stopped-flow experiments were also used to determine if $k_{\text {obs }}$ was affected by NADPH concentration. The stopped-flow absorbance changes were followed at $443 \mathrm{~nm}$ over $0.5 \mathrm{~s}$ and were fitted to a single exponential equation at concentrations of NADPH that were at least sevenfold greater than that of the enzyme concentration. The observed rate constant, $k_{\text {obs }}$, exhibited a hyperbolic saturation dependence on NADPH concentration, and a fit of the data to Eq. 6 yielded a $K_{\mathrm{d}}$ of $121 \pm 14 \mu \mathrm{M}$ and a $k_{\text {red }}$ (maximal rate constant of flavin reduction) of $59 \pm 3 \mathrm{~s}^{-1}$ (Table 2; Fig. 6b). The H325K elicited a similar rate of NADPH-dependent flavin reduction as the wild type enzyme; however, the observed rate constant was not dependent on NADPH concentration, which is consistent with this variant having a higher affinity for the coenzyme.

\section{Oxidative-half reaction}

Stopped-flow spectroscopy was used to monitor the catalytic events of the oxidative half-reaction. In the first experiment, the reduced enzyme in the presence of $500 \mu \mathrm{M} \mathrm{NADP}^{+}$was mixed with air-saturated buffer in the absence of ketone substrate. These mixing conditions lead to the formation of the C4a-peroxyflavin intermediate, which would subsequently decay to $\mathrm{H}_{2} \mathrm{O}_{2}$ and the fully oxidized flavin cofactor. For GSTACMO, the absorbance spectra were collected over 1.5 and $75 \mathrm{~s}$ on a logtime base and then subsequently combined; a selection of these spectra are shown in Fig. 7a. The time resolved spectra show initial formation of an absorbance peak at $366 \mathrm{~nm}$, demarking formation of the C4a-peroxyflavin intermediate following $\mathrm{O}_{2}$ activation by the reduced FAD cofactor. The absorbance at $440 \mathrm{~nm}$ subsequently increases reflecting decomposition of the C4a-peroxyflavin intermediate and reformation of the oxidized FAD cofactor. If the reaction is repeated with the presence of $200 \mu \mathrm{M}$ butanone in the air-saturated buffer, then formation of the C4a-peroxyflavin intermediate is less obvious, likely owing to its rapid decomposition in the presence of the carbonylic substrate (Fig. 7b). To extract rate constants for the kinetic events associated with the oxidative half reaction, we switched to single-wavelength mode with the stopped-flow apparatus, which enabled us to average multiple traces and acquire earlier data time points. In the absence of butanone, the absorbance changes at $366 \mathrm{~nm}$ were fit to a standard single exponential equation which gave an observed rate constant of $8.9 \pm 0.2 \mathrm{~s}^{-1}$, while the observed rate constants at $440 \mathrm{~nm}$ were $0.47 \pm 0.02 \mathrm{~s}^{-1}\left(k_{\text {ox } 1}\right)$ and $0.06 \pm 0.01 \mathrm{~s}^{-1}\left(k_{\mathrm{ox} 2}\right.$; Table 3$)$. When the reaction was repeated in the presence of $200 \mu \mathrm{M}$ butanone, then the observed rate constant at $366 \mathrm{~nm}$ was $6.5 \pm 0.8 \mathrm{~s}^{-1}$ and at $440 \mathrm{~nm}$, the single kinetic phase gave an observed rate constant $0.80 \pm 0.01 \mathrm{~s}^{-1}$ $\left(k_{440}\right)$. The observed rate constant for the formation of C4a-peroxyflavin at $366 \mathrm{~nm}$ was shown to increase with oxygen concentration (Fig. 8). From a linear fit of the observed rate constant versus oxygen concentration, we obtained a second order rate constant of $49 \mathrm{mM}^{-1} \mathrm{~s}^{-1}$ $\left(k_{\text {oo- }}\right)$ for the reaction between $\mathrm{O}_{2}$ and the reduced flavin. A similar bimolecular rate constant $\left(k_{\text {oo-BT }}\right)$ was obtained in the presence of butanone.

\section{Discussion}

Gordonia sp. strain TY-5 is a bacterium that is capable of utilizing gaseous propane as the sole course of carbon during aerobic growth. ACMO is part of the propane degradation pathway present in the bacterium, for which acetone is a central intermediate. Although ACMO was initially identified as acting in the catabolism of acetone (Kotani et al. 2007), the enzyme elicits a 700 -fold and 165 -fold lower catalytic efficiency towards this substrate relative to butanone and cyclobutanone respectively. Although PAMO shares $43 \%$ sequence similarity with ACMO, PAMO does not consume acetone (de Gonzalo et al. 2005; Fraaije et al. 2005). Instead, PAMO preferentially oxidizes small aromatic ketones, such as phenylacetone. Mutagenesis studies of PAMO point to an active site loop comprising residues $440-446$ as a structural feature that influences substrate specificity (Bocola et al. 2005; Reetz and Wu 2008). Deletion of residues S441 and A442 (PAMO numbering) resulted in an enzyme variant that was able to accept bulkier substrates (Bocola et al. 2005). Sequence alignment of PAMO and ACMO reveals that insertion of an alanine residue between S441 and A442, which may be a structural adaptation that restricts the ACMO active site and increase its catalytic efficiency towards smaller ketones such as acetone (Fig. 2). In ACMO, this residue (A433) improved catalytic efficiency towards small aliphatic ketones.

Stopped-flow spectroscopy was used to measure the rates of the reductive and oxidative half reactions. $\mathrm{NADPH}$-dependent reduction of the ACMO FAD cofactor was relatively fast with an observed rate constant of $\sim 60 \mathrm{~s}^{-1}$ at $25^{\circ} \mathrm{C}$. This rate constant is $\sim 3-5$-fold faster than that observed for CHMO and PAMO under similar experimental conditions (Ryerson et al. 1982; Torres Pazmino et al. 2008). However, the oxidative half reaction, particularly the formation of the C4a-peroxyflavin intermediate was considerably slower in ACMO. In $\mathrm{CHMO}$ and PAMO, the C4a-peroxyflavin adduct forms in $<10 \mathrm{~ms}$ at final $\mathrm{O}_{2}$ concentration of $\sim 0.3 \mathrm{mM}$, and the second-order rate constant was determined to be $870 \mathrm{mM}^{-1} \mathrm{~s}^{-1}$ for PAMO and $1700 \mathrm{mM}^{-1} \mathrm{~s}^{-1}$ for 
a

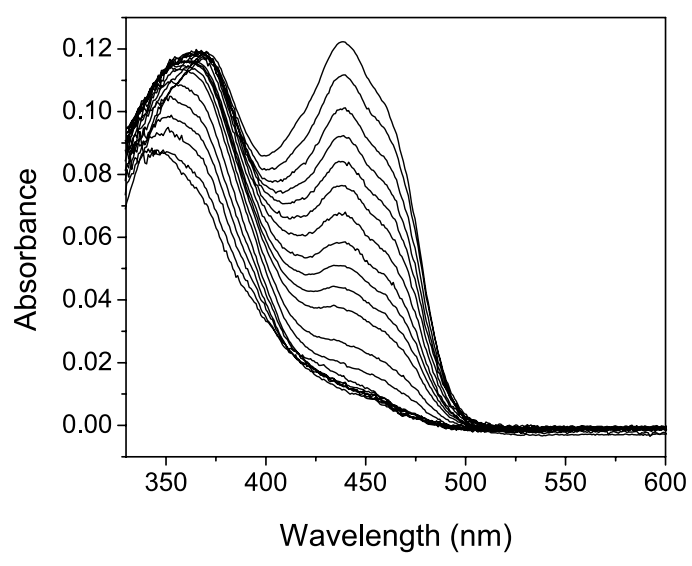

C

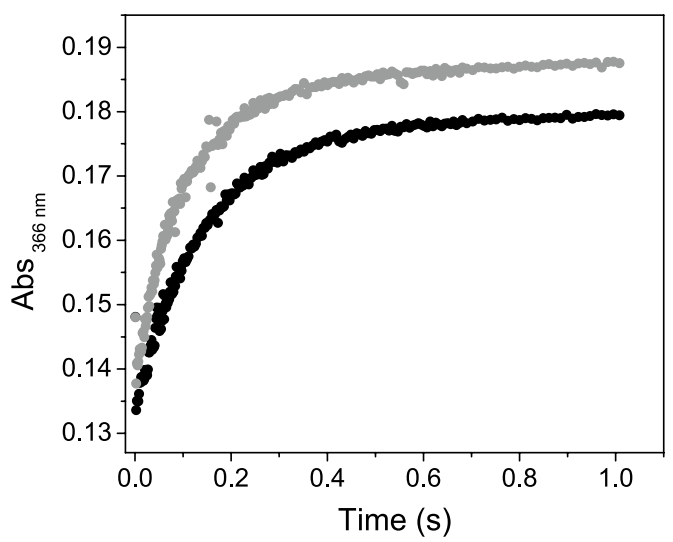

b

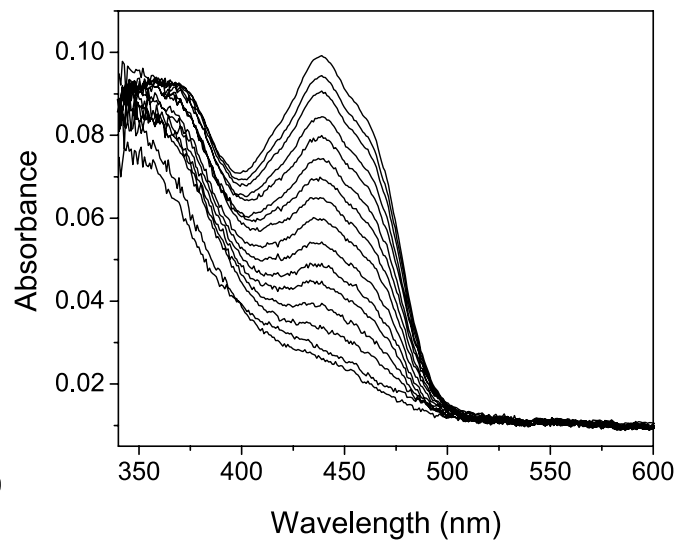

d

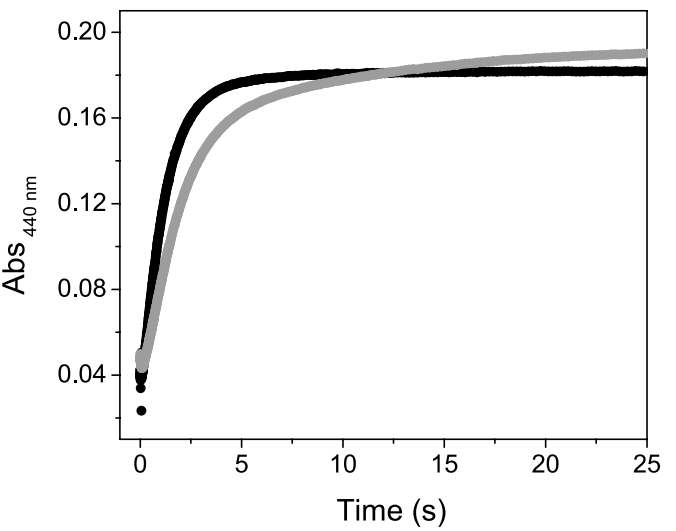

Fig. 7 a Time-resolved absorbance spectra collected over $75 \mathrm{~s}$ following the re-oxidation of reduced GSTACMO (20 $\mu \mathrm{M})$ in the presence $500 \mu \mathrm{M}$ $\mathrm{NADP}^{+}$with air-saturated buffer (50 mM HEPES pH 7.5, 20\% glycerol). b The same experiment as performed as for panel A with the exception of $200 \mu \mathrm{M}$ of butanone added to the air-saturated buffer. c Stopped-flow single wavelength traces at $366 \mathrm{~nm}$ following rapid mixing of reduced GSTACMO $(20 \mu \mathrm{M})$ in the presence $500 \mu \mathrm{M} \mathrm{NADP}^{+}$against air-saturated buffer (50 mM HEPES pH 7.5, 20\% glycerol) with $200 \mu \mathrm{M}$ of butanone (black circles) and without butanone (grey circles). Fitting the data to a single exponential equation gave observed rate constants of $6.5 \pm 0.8 \mathrm{~s}^{-1}$ (with butanone) and $8.9 \pm 0.2 \mathrm{~s}^{-1}$ (without butanone). $\mathbf{d}$ Stopped-flow single wavelength traces at $440 \mathrm{~nm}$ following rapid mixing of reduced GSTACMO $(20 \mu \mathrm{M})$ in the presence $500 \mu \mathrm{M}$ NADP ${ }^{+}$against air-saturated $50 \mathrm{mM}$ HEPES pH 7.5, 20\% glycerol with $200 \mu \mathrm{M}$ of butanone (black circles) and without butanone (grey circles). The absorbance traces with butanone were fitted to a single exponential equation giving an observed rate constant of $0.80 \pm 0.01 \mathrm{~s}^{-1}$, and the absorbance traces without butanone were fitted to a double exponential giving rate constants of $0.47 \pm 0.01 \mathrm{~s}^{-1}$ and $0.06 \pm 0.01 \mathrm{~s}^{-1}$

Table 3 Observed rate constants for the oxidative half reaction. The reactions were performed in $50 \mathrm{mM}$ HEPES$\mathrm{NaOH}, \mathrm{pH} 7.5$ at $25^{\circ} \mathrm{C}$

\section{Without butanone}

\begin{tabular}{|c|c|c|c|c|}
\hline $\begin{array}{l}k_{\text {oo }}^{-}\left(\mathrm{mM}^{-1}\right. \\
\left.\mathrm{s}^{-1}\right)^{\mathrm{a}}\end{array}$ & $k_{\mathrm{ox} 1}\left(\mathrm{~s}^{-1}\right)^{\mathrm{b}}$ & $k_{\mathrm{ox} 2}\left(\mathrm{~s}^{-1}\right)^{\mathrm{b}}$ & $\begin{array}{l}k_{\mathrm{OO}^{-} \mathrm{BT}} \\
\left(\mathrm{mM}^{-1} \mathrm{~s}^{-1}\right)^{\mathrm{a}}\end{array}$ & $k_{440}\left(\mathrm{~s}^{-1}\right)^{\mathrm{c}}$ \\
\hline $40.1 \pm 5.1$ & $0.47 \pm 0.01$ & $0.06 \pm 0.01 \mathrm{~s}^{-1}$ & $44.2 \pm 9.2$ & $0.80 \pm 0.01$ \\
\hline
\end{tabular}

${ }^{a}$ Determined from the slopes of a plot of the observe rate constants for the absorbance changes at $366 \mathrm{~nm}$ versus the concentration of dioxygen (Fig. 8)

b Determined from fitting a double exponential to the grey single wavelength absorbance trace at $440 \mathrm{~nm}$ shown in Fig. 7

c Determined from fitting a single exponential to the black single wavelength absorbance trace at $440 \mathrm{~nm}$ shown in Fig. 7
CHMO. In contrast, the second order rate constant for the reaction between $\mathrm{O}_{2}$ and the reduced FAD in ACMO $\left(49 \mathrm{mM}^{-1} \mathrm{~s}^{-1}\right)$ was 20 -30-fold lower. The C4a-peroxyflavin is also not as stable in ACMO even in the presence of saturating amounts of $\mathrm{NADP}^{+}$as it decayed with a rate constant of $0.47 \mathrm{~s}^{-1}$ in the absence of substrate. The instability of the C4a-peroxyflavin intermediate likely accounts for the relatively high rate of uncoupled NADPH oxidation $\left(0.26 \mathrm{~s}^{-1}\right)$ in ACMO. The NADPH oxidase activity of CHMO and PAMO is 50-fold and 150fold lower, respectively, than that of the monooxygenase activity (Torres Pazmino et al. 2008; Sheng et al. 2001), but in ACMO it is only tenfold lower. It is unclear why 


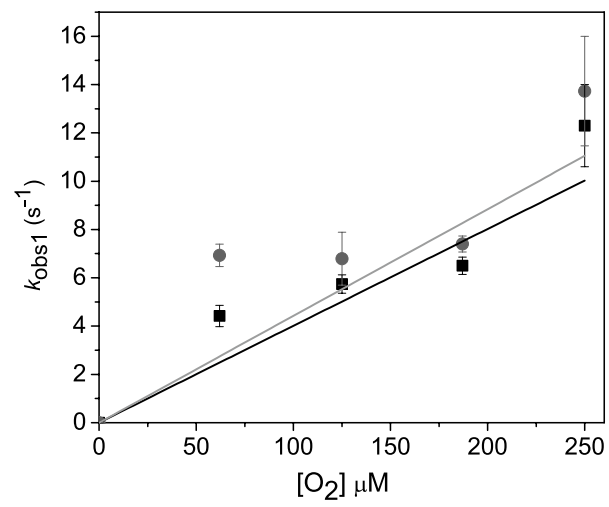

Fig. 8 The dependence of the $k_{\text {obs } 1}$ measured at $366 \mathrm{~nm}$ on $\left[\mathrm{O}_{2}\right]$. The observed rate constants were plotted as a function of $\left[\mathrm{O}_{2}\right]$ in the absence (closed squares) and presence of $200 \mu \mathrm{M}$ butanone (closed circles) for GSTACMO. The slope of the lines were used to determine the bimolecular rate constants ( $k_{\mathrm{oO}-}$ and $k_{\text {оO-BT }}$ ) shown in Table 3

this may be the case in ACMO, but it may be linked to the enzyme's relatively weak binding affinity for NADP ${ }^{+}$.

Steady-state inhibition studies revealed that the $\mathrm{NADP}^{+}$binding affinity is $\sim 166 \mu \mathrm{M}$, similar to the dissociation constant for NADPH $(120 \mu \mathrm{M})$ determined through stopped-flow experiments. By way of contrast, the $K_{\mathrm{d}}$ for NADPH is $0.7 \mu \mathrm{M}$ and $11 \mu \mathrm{M}$ for PAMO and CHMO, respectively (Torres Pazmino et al. 2008; Ryerson et al. 1982). Interestingly, the dissociation constant for the oxidized coenzyme determined through titration experiments was significantly lower at $21 \mu \mathrm{M}$. It unclear why a discrepancy is observed in the experimentally determined $K_{\mathrm{d}}$ values. It may have to do with the oxidation state of the coenzyme or enzyme. The stopped flow experiments measure the binding affinity of NADPH for the oxidized enzyme, steady-state inhibition studies measure the binding affinity of $\mathrm{NADP}^{+}$for the reduced enzyme and the titration experiments measure the binding affinity of $\mathrm{NADP}^{+}$to the oxidized enzyme. Previous studies have experimentally shown that the redox state of the enzyme can modulate the binding affinity for the pyridine nucleotide (van den Heuvel et al. 2005).

Crystal structures of $\mathrm{CHMO}$ and PAMO in complex with $\mathrm{NADP}^{+}$show the coenzyme in an extended conformation, wedged between the Rossmann-fold of the NADP-domain and a loop within the FAD domain (Fig. 2). Residues coordinated to the coenzyme in PAMO are conserved in ACMO, with the exception of Lys ${ }^{336}$ (PAMO numbering), which coordinates to the 2'-phosphate of the coenzyme. Mutagenesis of the lysine in HAPMO $\left(\right.$ Lys $^{429}$ ) demonstrates its importance in increasing the binding affinity of NADPH and ensuring that the enzyme preferentially selects for NADPH over NADH. In ACMO, the lysine to histidine substitution does not affect the enzyme's preference for NADPH over NADH as both the wild type enzyme and the $\mathrm{H} 325 \mathrm{~K}$ variant were unable to catalyze the oxidation of NADH. The substitution does however strengthen the enzyme's affinity for the 2'-phosphorylated coenzyme by sixfold.

In summary, we have shown that AMCO elicits the highest catalytic efficiency towards butanone and cyclobutanone. The enzyme also elicits a relatively weak binding affinity for $\operatorname{NADP}(\mathrm{H})$, which is partially attributed to sequence variation in the 2 -phosphate binding pocket. Reduced ACMO also reacts more slowly with $\mathrm{O}_{2}$ and is less efficient at stabilizing the C4a-peroxyflavin adduct compared to related BVMOs. As a consequence, ACMO elicits a relatively high NADPH oxidase activity compared to its monooxygenase activity. Finally, kinetic isotope studies support transfer of the pro $R$ hydrogen. This implies that the re-face of the nicotinamide ring is planner with the FAD for reductive half reaction. Following hydride transfer the enzyme and cofactor undergo a conformational switch that places the $s i$-face of the nicotinamide ring over the FAD, in position to stabilize reactive oxygenating intermediates of the oxidative half reaction.

\section{Additional file}

Additional file 1: Fig.S1. A $10 \%$ SDS-PAGE gel of recombinant ACMO. Lane 1, molecular weight markers; lane 2, crude extract; lane 3, glutathione-sepharose showing the GST-ACMO chimera and lane 4, recombinant $\mathrm{ACMO}$ following $\mathrm{Q}$-sepharose chromatography.

\section{Authors' contributions}

OBF performed all the experiments and data analysis, KRW designed the experiments and wrote the manuscript, GL purified protein and $\mathrm{MH}$ initiated the project and provided supervision. All authors read and approved the final manuscript.

\section{Author details}

${ }^{1}$ Department of Chemistry, University at the British Columbia, Okanagan Campus, 3247 University Way, Kelowna, BC V1V 1V7, Canada. ${ }^{2}$ School of Engineering, University at the British Columbia, Okanagan Campus, 3247 University Way, Kelowna, BC V1V 1V7, Canada.

\section{Competing interests}

The authors declare that they have no competing interests.

\section{Availability of data and materials}

All relevant data are presented in the main paper.

Consent for publication

Not applicable.

Ethics approval and consent to participate Not applicable.

Funding

This work is supported by a grant from the Natural Sciences and Engineering Research Council of Canada (RGPIN-2015-06130). 


\section{Publisher's Note}

Springer Nature remains neutral with regard to jurisdictional claims in published maps and institutional affiliations.

Received: 23 August 2018 Accepted: 29 October 2018

Published online: 03 November 2018

\section{References}

Balke K, Kadow M, Mallin H, Sass S, Bornscheuer UT (2012) Discovery, application and protein engineering of Baeyer-Villiger monooxygenases for organic synthesis. Org Biomol Chem 10(31):6249-6265. https://doi. org/10.1039/c2ob25704a

Bocola M, Schulz F, Leca F, Vogel A, Fraaije MW, Reetz MT (2005) Converting phenylacetone monooxygenase into phenylcyclohexanone monooxygenase by rational design: towards practical Baeyer-Villiger monooxygenases. Adv Synth Catal 347(7-8):979-986

Bowman MJ, Jordan DB, Vermillion KE, Braker JD, Moon J, Liu ZL (2010) Stereochemistry of furfural reduction by a Saccharomyces cerevisiae aldehyde reductase that contributes to in situ furfural detoxification. Appl Environ Microbiol 76(15):4926-4932

de Gonzalo G, Pazmino DET, Ottolina G, Fraaije MW, Carrea G (2005) Oxidations catalyzed by phenylacetone monooxygenase from Thermobifida fusca. Tetrahedron Asymmetry 16(18):3077-3083

de Gonzalo G, Mihovilovic MD, Fraaije MW (2010) Recent developments in the application of Baeyer-Villiger monooxygenases as biocatalysts. ChemBioChem 11(16):2208-2231. https://doi.org/10.1002/cbic.201000395

Donoghue NA, Norris DB, Trudgill PW (1976) The purification and properties of cyclohexanone oxygenase from Nocardia globerula CL1 and Acinetobacter NCIB 9871. Eur J Biochem 63(1):175-192

Fraaije MW, Wu J, Heuts DP, van Hellemond EW, Spelberg JH, Janssen DB (2005) Discovery of a thermostable Baeyer-Villiger monooxygenase by genome mining. Appl Microbiol Biotechnol 66(4):393-400. https://doi. org/10.1007/s00253-004-1749-5

Hausinger RP (2007) New insights into acetone metabolism. J Bacteriol 189(3):671-673. https://doi.org/10.1128/JB.01578-06

Kamerbeek NM, Fraaije MW, Janssen DB (2004) Identifying determinants of NADPH specificity in Baeyer-Villiger monooxygenases. Eur J Biochem 271(11):2107-2116. https://doi.org/10.1111/j.1432-1033.2004.04126.x

Kolek T, Szpineter A, Swizdor A (2008) Baeyer-Villiger oxidation of DHEA, pregnenolone, and androstenedione by Penicillium lilacinum AM111. Steroids 73(14):1441-1445. https://doi.org/10.1016/j.steroids.2008.07.008

Kotani T, Yurimoto H, Kato N, Sakai Y (2007) Novel acetone metabolism in a propane-utilizing bacterium, Gordonia sp. strain TY-5. J Bacteriol 189(3):886-893. https://doi.org/10.1128/jb.01054-06
Leisch H, Morley K, Lau PC (2011) Baeyer-Villiger monooxygenases: more than just green chemistry. Chem Rev 111(7):4165-4222. https://doi. org/10.1021/cr1003437

Mascotti ML, Juri Ayub M, Dudek H, Sanz MK, Fraaije MW (2013) Cloning, overexpression and biocatalytic exploration of a novel Baeyer-Villiger monooxygenase from Aspergillus fumigatus Af293. AMB Express 3(1):33. https://doi.org/10.1186/2191-0855-3-33

Mascotti ML, Kurina-Sanz M, Juri Ayub M, Fraaije MW (2014) Insights in the kinetic mechanism of the eukaryotic Baeyer-Villiger monooxygenase BVMOAf1 from Aspergillus fumigatus Af293. Biochimie 107(Pt B):270-276. https://doi.org/10.1016/j.biochi.2014.09.005

Massey V (1991) A simple method for the determination of redox potentials. In: Curti B, Ronchi S, Zanetti G (eds) Flavins and flavoproteins. DeGruyter W. \& Co, Berlin, pp 59-66

Reetz MT, Wu S (2008) Greatly reduced amino acid alphabets in directed evolution: making the right choice for saturation mutagenesis at homologous enzyme positions. Chem Commun 43:5499-5501. https:// doi.org/10.1039/b813388c

Rehdorf J, Zimmer CL, Bornscheuer UT (2009) Cloning, expression, characterization, and biocatalytic investigation of the 4-hydroxyacetophenone monooxygenase from Pseudomonas putida JD1. Appl Environ Microbiol 75(10):3106-3114. https://doi.org/10.1128/AEM.02707-08

Ryerson CC, Ballou DP, Walsh C (1982) Mechanistic studies on cyclohexanone oxygenase. Biochemistry 21(11):2644-2655

Sheng D, Ballou DP, Massey V (2001) Mechanistic studies of cyclohexanone monooxygenase: chemical properties of intermediates involved in catalysis. Biochemistry 40(37):11156-11167

Torres Pazmino DE, Baas BJ, Janssen DB, Fraaije MW (2008) Kinetic mechanism of phenylacetone monooxygenase from Thermobifida fusca. Biochemistry 47(13):4082-4093. https://doi.org/10.1021/bi702296k

Torres Pazmino DE, Dudek HM, Fraaije MW (2010) Baeyer-Villiger monooxygenases: recent advances and future challenges. Curr Opin Chem Biol 14(2):138-144. https://doi.org/10.1016/j.cbpa.2009.11.017

van den Heuvel RH, Tahallah N, Kamerbeek NM, Fraaije MW, van Berkel WJ, Janssen DB, Heck AJ (2005) Coenzyme binding during catalysis is beneficial for the stability of 4-hydroxyacetophenone monooxygenase. J Biol Chem 280(37):32115-32121. https://doi.org/10.1074/jbc.M503758200

Webb B, Sali A (2014) Protein structure modeling with MODELLER. Methods Mol Biol 1137:1-15. https://doi.org/10.1007/978-1-4939-0366-5_1

\section{Submit your manuscript to a SpringerOpen ${ }^{\odot}$ journal and benefit from:}

- Convenient online submission

- Rigorous peer review

- Open access: articles freely available online

- High visibility within the field

Retaining the copyright to your article

Submit your next manuscript at $\boldsymbol{\nabla}$ springeropen.com 